\title{
Critical Legal Studies: A Political History
}

\author{
Mark Tushnet $\dagger$
}

I imagined that an article on critical legal studies in a centennial issue like this one ought to be an exposition of the origins of the ideas of critical legal studies and a description of the lines of inquiry that are open for future work in the field. In light of the content of critical legal studies, I imagined as well that the form of the presentation ought not be the standard expository essay. On reflection, however, I concluded that, though I had to avoid the expected content, I could not depart from the standard form. ${ }^{1}$ I had to avoid the expected content because critical legal studies is less an intellectual movement in law (though it is that too) than it is a political location. ${ }^{2}$ By describing the political location that is critical legal studies, I hope to indicate what its intellectual content is and sketch its possible future. The story of critical legal studies is

† Professor of Law, Georgetown University Law Center. When a draft of this Article was circulated to some people in critical legal studies, the recipients disagreed substantially with much of it. I have profited from the comments I received, and have modified my presentation in response. Because I do not think that I have changed the substance of the argument, however, and in light of the depth of the disagreement, the standard disclaimer may not be sufficient to remove the taint of association with the Article. Those who read it know who they are, and $I$ thank them for their comments.

1. "Could not" because of my concern that departures from the standard form require a degree of technical competence in writing that I lack. I have been uncomfortable with the publication of law review articles in the form of short stories, or short stories in the form of law review articles, because they strike me as yet another manifestation of the "lawyer as astrophysicist" mentality that I have criticized. See Tushnet, Truth. Justice, and the American Way: An Interpretation of Public Law Scholarship in the Seventies, 57 TEX. L. REV. 1307, $1338 \mathrm{n} .140$ (1979). This was brought home to me in a conversation with a former roommate, now a professor of literature, in which my wife and I were trying to identify the author of a line of poetry quoted in a newspaper puzzle. My friend immediately began by saying something like, "Well, it couldn't be by $X$ because the line is too long for him." I realized then that there is a world of understanding about literature to which I essentially have no access, and I now wonder about the degree to which other law professors do. The cynical version of this point is that if law professors could write short stories, they would be short-story writers rather than law professors. On the other hand, my cynicism is tempered by my recollection of the short stories my father wrote. After he retired from medical practice, he wrote what I think of as Jewish science fiction. He was not a particularly elegant writer, but the novelty of the content was frequently enough to sustain interest in his stories. So too, perhaps, with law review articles in the form of short stories. The appearance of my former roommate and my father in this footnote is not adventitious. See infra pp. 1533-34, 1536.

2. I use the word "location" to convey the sense that critical legal studies is a place where people with a wide but not unlimited range of political views can come together for political education, sustenance, and activity. "Place" is of course a metaphor, perhaps more accurate but more verbose would be the suggestion that critical legal studies is a form of self-identification that allows people to recognize each other as basically sympathetic to a broad but not all-encompassing political agenda. That recognition occurs at professional meetings, in law school faculties, and through the reading of the professional literature. 
a story of how the legal academy simultaneously tolerates and contains a radical political location. ${ }^{3}$

\section{PRESENT History}

From the inside there is something awkward in talking about critical legal studies as a "movement" or "school." As I read articles by and about critical legal studies, I not infrequently find myself puzzled. The authors of the articles provoking this reaction describe what they believe critical legal studies to be, and yet the descriptions do not resonate strongly with what I think about the law. Where the articles are merely descriptive, or are written by critics of cls, ${ }^{4}$ I can dismiss my reaction by saying to myself that these critics or outsiders do not understand what cls is. Where the articles are by people whom I regard as co-participants in the enterprise of critical legal studies, however, that response is unavailable to me. So when I find these authors taking as central to their understanding of cls propositions that I find extremely problematic, or dismissing as unimportant propositions that I find central, I have to figure out what is going on. After all, I know that I am supposed to be associated with critical legal studies in some important way.

The most plausible explanation, and the one I explore here, is that critical legal studies is a political location for a group of people on the Left who share the project of supporting and extending the domain of the Left in the legal academy. ${ }^{5}$ On this view the project of critical legal studies does not have any essential intellectual component, ${ }^{6}$ which is why I cannot readily identify a great

3. Initially I had decided not to include reference to specific items of cls in this Article. I was concerned that readers would interpret it as an attempt to adjudicate claims of entitlement to the cls mantle, which would be particularly problematic because I would be doing so after having accepted the invitation of the editors of The Yale Law Journal to write it. The editors have persuaded me, however, that the absence of citations would make the Article seem directed solely to insiders to cls, itself a difficulty in light of their invitation, and that the absence would make my points seem to float free. I have responded to that concern by relying, to the greatest extent possible, on work identified as cls by other people. I must note my residual concerns that my citation strategy will fail to identify people and their work which ought to be included in the account, and that it may include people who have good reasons for objecting to their inclusion. For a bibliography of cls work up to 1984, see Kennedy \& Klare, A Bibliography of Critical Legal Studies, 94 YALE L.J. 461 (1984); a more recent selective bibliography, updated through August 1989, is available from Professor Richard Bauman, Faculty of Law, University of Alberta. R. Bauman, Critical Legal Studies: Selected Bibliography (Aug. 1989) (unpublished manuscript on file with author).

4. In this Article I use "cls" rather than "CLS" because it abbreviates a description of legal studies that are critical, so that the words prefacing "studies" are ordinary adjectives. In addition, I believe that the usual form is "law and economics," not "Law and Economics." The typography may convey a sense of what is ordinary and what is extraordinary in legal studies, and I want to take a position on that question.

5. I do not consider the possibility that cls is coextensive with the Left of the legal academy, because there are obviously some people on the Left who do not consider themselves to be part of cls.

6. In this formulation, "essential" carries a great deal of weight. At any time there will undoubtedly be a substantial number of general propositions on which most people committed to the cls project agree ("law is politics," "law is substantially indeterminate," "law is a form of mystification, among other things," for example). But, first, agreement on the general level says nothing about the particular content people will give to those propositions (itself a cls point), and second, as the political location develops, the propositions on which there is general agreement will change, as they already have. 
deal that is common in the intellectual production going under the heading of critical legal studies. ${ }^{7}$ There should be nothing surprising about this conclusion, of course, in light of the proposition common to most cls authors that law is politics. For, if law is politics, presumably one might also believe that legalintellectual positions are politics too. Treating cls as a political location may illuminate the meaning of the claim about law and politics as well. When people associated with cls assert that law is politics, I take them to mean that when one understands the moral, epistemological, and empirical assumptions embedded in any particular legal claim, one will see that those assumptions operate in the particular setting in which the legal claim is made to advance the interests of some identifiable political grouping. ${ }^{8}$ Yet people who seek to advance the interests of a single group may make varying underlying assumptions, with the result that some in the "movement" will find themselves disagreeing with the legal claims asserted by others who, they agree, are also in the movement. It is in that sense that critical legal studies can be understood as a political location notwithstanding the disagreements among participants in the movement. ${ }^{9}$ At present one might describe the political location of critical legal studies as occupied by certain feminists ("fem-crits"), ${ }^{10}$ certain theorists concerned with the role of race in law (critical race theorists), ${ }^{11}$ a group influ-

7. One strand in cls, labeled below the postmodemist, asserts that the description in the text must be accurate because there are no "essential intellectual components" of any enterprise, but only positions that people take. For reasons I discuss below, I disagree with that strand. (But, of course, what else could I do but take a position? That is, to write a political history of cls in another way would be to demonstrate or embody a commitment to a different strand in cls. For example, one might write a political history that focused on the numerous-in my mind, innumerable-occasions when attempts to develop a formal structure for the movement were beaten back, and on the networks of personal contacts that constitute cls. To do so, however, would be to become a part of cls in a different way from the way in which I have become a part of the movement.)

8. Note that I do not take the claim to be that those assumptions necessarily or in all settings operate to advance the interests of an identifiable political grouping.

9. The enumeration that follows should not be taken to suggest that the groups have rigid boundaries, such that a person identified by me or others as falling in one group necessarily cannot fall in another. In fact, everyone associated with cls has been influenced to varying degrees by people in each of the groups, though it does seem to me that almost all of us find our centers of gravity closer to only one of the groups. Professor Bauman's bibliography has a section entitled "The Special Role of Roberto Unger," see R. Bauman, supra note 3, at 2, and in my view Duncan Kennedy has a similar role; they are, more than most, unclassifiable in the categories I use in this Article.

10. For an informal history of the fem-crits, see Menkel-Meadow, Feminist Legal Theory, Critical Legal Studies, and Legal Education, or, "The Fem-Crits Go to Law School," 38 J. LEGAL EDUC. 61, 62-66 (1988). Menkel-Meadow identifies herself, Jeanne Charn, Clare Dalton, Ann Freedman, Mary Joe Frug, Nancy Gertner, Judi Greenberg, Martha Minow, Frances Olsen, Elizabeth Schneider, and Robin West as "fem-crits." (She also identifies others as feminists tout court; in light of the critical dimensions of feminist jurisprudence, the classifications here may be particularly inexact and probably should be developed entirely by finding out who identifies herself as a fem-crit.) I use the term "fem-crits" because it is used by many of those who identify themselves as fem-crits. In this Article I have otherwise tried to refrain from using the term "crits" and have used more awkward constructions such as "adherents of critical legal studies" because, for myself, I find the term "crits" marginalizing and when used by adherents of critical legal studies almost an intemalization of that marginalization. I am unsure whether the term "fem-crits" operates in the same way.

11. Mari Matsuda, in Pragmatism Modified and the False Consciousness Problem, 63 S. CAL. L. REV. 1763, 1763 n.3 (1990), identifies herself, Regina Austin, Derrick Bell, John Calmore, Kimberle Crenshaw, 
enced by recent developments in literary theory (postmodernists), ${ }^{12}$ a group of cultural radicals, ${ }^{13}$ and a group that stresses the role of the economic structure in setting the conditions for legal decisions (political economists). ${ }^{14}$

Even on this description of the location, however, there do seem to be some common elements to that which is found there. If critical legal studies is the location for people who identify themselves with a particular political project, that project is located in the legal academy. For the people involved in the project, the psychology of self-identification may require that they see themselves as sharing certain intellectual commitments, in order to be a political location in the academy rather than, for example, a political location in electoral politics. And, in general, there does seem to be a sufficient degree of commitment to three propositions about law: that it is in some interesting sense indeterminate; that it can be understood in some interesting way by paying attention to the context in which legal decisions are made; and that in some interesting sense law is politics. ${ }^{15}$

My effort to describe cls as a political location would be distorted were I to attempt to specify in much detail the different ways in which people have developed the implications of these rather vague propositions. In the course of my presentation I will put a little more flesh on the bones, but to do more would be to suggest, erroneously, that in my understanding of the enterprise the intellectual content of various cls positions has a higher priority than cls' functions as a political location. Further, like all political locations, cls has an internal politics, some aspects of which I will discuss, and an external politics, which is my primary concern. ${ }^{16}$ The external politics of cls consists of its relations with the settings in which its adherents find themselves. The details of cls positions have played a relatively small role in those external politics-in

Harlon Dalton, Richard Delgado, Charles Lawrence, Gerald López, Gerald Torres, Patricia Williams, and Robert Williams as associated with critical race theory.

12. Hunt, The Big Fear: Law Confronts Post-Modernism, 35 MCGாL L.J. 507, 512 n.7 (1990), lists the following United States scholars as authors of "some of [the] more interesting manifestations" of postmodernism: Jack Balkin, Drucilla Cornell, Clare Dalton, Gerald Frug, Christine Desan Husson, and Gary Peller.

13. Peter Gabel is the most prominent of this group.

14. As this Article indicates, I associate myself with this last group. Others include Wythe Holt, Morton Horwitz, Karl KIare, and Katherine Stone. Given the aim of this Article to describe the toleration and containment of critical legal studies by the mainstream legal academy, I will not say much about the merits of the contributions made by scholars affiliated with other strands of critical legal studies, except that their work is extremely interesting, has flaws like everything else, and deserves more extended attention than I could give it here.

15. I argue in the next Part that these propositions are related efforts to answer the question, "How does one theorize a leftist stance in law after legal realism and the critique of social theory?"

16. My comments about the internal politics of cls may suggest, erroneously, that there are deeper divisions within the location than actually exist. In fact, discussions within cls indicate that we share far more in our common opposition to a system of illegitimate hierarchy than we disagree among ourselves. 
large part, I believe, because those outside the movement have had little inclination to attend to these details. ${ }^{17}$

Critical legal studies has become one of the accepted elements in the pluralistic universe of legal scholarship. Law faculties believe that it is generally a good thing to have one (but not more than one) cls advocate in the building, ${ }^{18}$ although, as is usual in the assimilation of a novel approach to law, they frequently find particularized objections to each specific advocate proposed for appointment. ${ }^{19}$ One reason for this degree of acceptance lies in the hierarchical politics of the legal academy. There are now enough cls people at leading law schools that some of the authority flowing from hierarchy has attached to cls work. $^{20}$

Another reason lies in the general politics of the country. The intellectual vitality of the Center-Left, which is the location of most legal academics, has quite simply disappeared. In law, people continue to go through the motions of defending center-left substantive positions and center-left jurisprudence, but

17. For example, if people interested in law and economics spent one tenth of the time understanding critical legal studies that cls people spend understanding law and economics, we would all be better off. It is instructive to compare the relative sophistication of the treatment of law and economics in M. KELMAN, A GUIDE TO CRITICAL LEGAL STUDIES (1987), with that of critical legal studies in R. POSNER, PROBLEMS OF JURISPRUDENCE (1990).

18. There is resistance to the appointment of more than one cls advocate because of the entirely unwarranted view that their political commitments dictate that they will not be good colleagues, but will go around stirring up trouble by attempting to indoctrinate students in the classroom (as if the presentation of moderation and balance as the style and content of law is not indoctrination), or voting on hiring decisions with regard solely to politics rather than the merits (as if the definition of "the merits" were so incontestable that only efforts to question the definition are necessarily political). As to the latter point, I think it worth pointing out that I am hard-pressed to identify a leading law faculty that has denied tenure to someone prominently identified as a right-wing law and economics person, and find it absurdly easy to identify faculties that have denied tenure to cls people. (I use "deny tenure" in the accepted sense that includes sending strong messages that it would not be a wise move on the applicant's part to go through the formal tenure process.) One might hypothesize, of course, that it is not politics that leads to the denial of tenure to people identified with the Left, but rather that, because of the political views held by these junior faculty, it is more common for law faculties to misjudge their merits at the appointment stage. To the extent this hypothesis rests on the proposition that law faculties are better at assessing the merits of right-wing people than of left-wing people, it hardly means that law faculties are nonpolitical. (The denial of tenure at Stanford Law School to Richard Markovits, a non-right-wing law and economics scholar, presents some special problems, but my judgment is that this denial is consistent with the hypothesis that faculties systematically misjudge the merits of people with nonstandard political views.)

19. In addition, there appears to be something akin to a "deviance quota" operating in faculty hiring. Deviance can be defined in a variety of ways, incorporating, for example, people interested in law and economics (less so today than in the recent past), people interested in law and literature, people interested in critical legal studies, women, and minorities. A faculty's definition of deviance and the size of its deviance quota may limit the opportunities for any more deviants to be hired, whether they be adherents of critical legal studies, women, or minorities.

20. This authority has simultaneously presented critical legal studies with some internal political problems. It has eased somewhat the task of recruitment to critical legal studies, particularly because many potential law teachers actually attend the high-status schools at which prominent adherents of cls teach. At the same time, the same prominent adherents receive a degree of deference within cls that generates resentment among those who find themselves studying or teaching at schools lower in the status rankings. (This observation is predicated on the fact that not everyone associated with critical legal studies completely lacks aspirations for recognition by institutions able to confer high status, even as we believe that there is no particularly good reason why those institutions should be able to confer such status.) 
it has become almost tiresome even to the people doing the work. ${ }^{21}$ In addition, the rightward drift of the nation's politics has induced a similar drift in what is regarded as the Center-Left; to be just to the left of the middle of the policy spectrum today, one must be advocating policies that would have been regarded as quite conservative two decades ago. ${ }^{22}$ Yet center-left legal academics know they used to believe something else, more like the egalitarian views associated with cls. Though they do not feel themselves to be in bad faith, they tend to recognize in cls the defense of positions they once held and with which they still feel some sympathy.

A third reason for the embedding of cls in the pluralistic universe derives from the proliferation of alternative, but dissident, legal theories by feminist and minority scholars. Here the political story is quite complex. ${ }^{23}$ Friendly criticism by these scholars of certain aspects of critical legal studies turns out, somewhat paradoxically, to enhance the role of those aspects. Center-left legal academics have some degree of commitment to increasing the diversity of the academy. I put it in those terms, rather than saying "affirmative action," because the way in which the academy has justified its affirmative action efforts has been to invoke the value of diverse perspectives in enriching our understanding of the law. Yet once faculties articulate the value at stake to be diversity as such, they find it difficult to resist the intellectual pressure to incorporate political diversity as well..$^{24}$

In addition, some feminist and minority scholars who share the cls political location have disagreed with some formulations of the indeterminacy thesis, and in particular with the use of that thesis to challenge the importance of the vindication of rights, especially constitutional rights. ${ }^{25}$ Centrist liberals have responded to what they see as two aspects of this criticism of the critique of rights. First, the criticism accepts large portions of cls claims about indetermina-

21. Recent events in central Europe are likely to revitalize the rhetoric of center-left policy and jurisprudence. See infra pp. 1537-38. There seems to me a complete cls response, invoking a rather weak form of the indeterminacy thesis, to the claim that those events demonstrate the superiority of capitalist democracy: What sort of savings and loan institutions are entailed by the establishment of capitalist democracy in eastern Europe?

22. Perhaps the best example is the changed discourse about public responsibility for the provision of health care. The present centrist-liberal position is that there should be public provision of health care insurance for those not covered by private insurance systems; the vision of the Great Society, I think, was that there should be public provision of health care, period.

23. I doubt that this footnote will defuse the political problems that my statements in the text may create. However, it seems appropriate even so to say that, in my effort to describe the politics of cls, I will be speaking more of center-left academics and cls scholars as actors in the political process, and less of feminist and minority scholars as such actors.

24. Difficult, but not impossible. My sense is that it is just as difficult these days for a dedicated conservative (at least one who does not specialize in right-wing law and economics) to get a job on many law faculties as it is for a cls person to do so. For a suggestion that this results in part from the fact that there are structural reasons why center-left academics are likely to see conservatives seeking jobs in the legal academy as less "qualified" than cls people, see infra text accompanying note 92.

25. A selection from a rich literature may be found in Minority Critiques of the Critical Legal Studies Movement, 22 HARV. C.R.-C.L. L. REV. 297 (1987). My most recent contribution to this discussion is Tushnet, Rights: An Essay in Informal Political Theory, 17 POL. \& Soc'Y 403 (1989). 
cy and the alienating quality of appeals to the rule of law, and adds to them more radical feminist and racialist critiques. The premise of the criticism tends to be that the cls critique of rights fails adequately to understand the role that ideologies of rights, understood as such, have played in the historical construction of liberation movements. ${ }^{26}$ Second, however, the criticism has an ambivalent tone to it, in part because it results from the critics' attempts to establish a scholarly identity that is independent of prior work and in part because it results from the critics' rejection of the intellectual and academic hierarchy that was part of the reason the critique of rights became influential.

On law faculties, for example in discussions about hiring, some centrist liberals reacted to feminist and minority criticisms of the critique of rights as more of the same radical nonsense. Others, though, amplified the ambivalence present in the critics' works in an effort to domesticate this strand of minority and feminist scholarship, treating it as rejecting (rather than engaging in a political dialogue with) the cls critique of rights. Because of their need to present themselves as politically progressive, they constructed a political position to their left but to the right of cls, into which they placed certain minority and feminist scholars. The existence of a critique of rights within cls allows centrist liberals to treat the minority and feminist responses to that aspect of cls as differentiating feminist and minority scholarship from "real" cls. In this way, the constructed "real" cls serves as a useful negative reference point for centrists and liberals. ${ }^{27}$

At least in the initial stages of the process of expanding the legal academy to include feminist and minority scholars, though, this strategy has beneficial consequences for cls. It creates some opportunities for radical feminist and minority scholars, through the agency of centrist liberals, when those same liberals have been erecting barriers to the advancement of others associated with cls. Yet these radical feminist and minority scholars, precisely because they are engaged in a common project with other cls scholars, see critical legal studies as a project that deserves support. In addition, most feminist and minority scholars, associated with cls or not, recognize that in the internal politics of law schools, cls people are likely to be on their side more often than people on the Center-Left or rightward. ${ }^{28}$ Finally, the centrist-liberal strategy will work only if there are enough "real" cls people around to make them a credible negative

26. Having participated in the construction of the critique of rights, $I$ take it as a point of personal privilege to note that I disagree with this evaluation of the critique's appreciation of the role of rightsideologies in liberation movements. For my engagement with this question, see generally M. TUSHNET, THE NAACP'S LEGAL STRATEGY AGAINST SEGREGATED EDUCATION, 1925-1950 (1987).

27. One identified with cls can find this phenomenon a little irritating, though one can live with the irritation in light of the political importance of expanding the academy to include feminist and minority scholars. Indeed, one might characterize a function of cls as prying open some space for those scholars.

28. "Likely" and "more often," not "always on every issue," thus creating a certain degree of tension in the relationship. 
reference point. ${ }^{29}$ The dynamics of the process, then, are to make cls in all of its versions an acceptable part of the pluralistic universe. ${ }^{30}$

The situation in the legal academy should not be regarded complacently, for there are substantial barriers to the further development of the political location that is critical legal studies. I deal with some of those barriers in Part $\mathrm{V}$, but one deserves attention here. In the early stages of the development of cls, people could be hired without anyone knowing that they were "crits," 31 either because the movement had not yet come together or because the applicants had not yet undergone the political transformation into critical legal scholars. As a result, discrimination against cls tended to occur at the tenure stage. It was then more visible, and it affected people who had built up friendships among wider groups of the faculties involved, which meant that political discrimination was more difficult than it might have been at an earlier stage. Today, in contrast, such discrimination tends to occur at the point of hiring. Applicants are asked to define their position with respect to cls or, even worse, positions are imputed to applicants based on the courses they took, the people who have supported them for appointment, and the like. At the hiring stage, applicants for positions almost by definition do not have close ties to members of the faculty doing the hiring, so the latter have a smaller investment of the emotions that lead them to fight hard when tenure denials are involved. Discrimination is thus more difficult to discern ("We just didn't need someone in your field this year"), and political battles therefore more difficult to wage.

One still hears a certain amount of demonizing of cls, often in the form of genteel redbaiting, ${ }^{32}$ and there is enough anti-intellectual Babbitry in the legal academy to suggest that there are limits to the degree to which cls can really become entrenched in the pluralistic universe. ${ }^{33}$ For the present, considering

29. In the unlikely event that feminist and minority viewpoints become entrenched in the legal academy, the utility of cls as a negative reference point will diminish. We are not yet near that point.

30. In my view, cls has incurred some costs in the process of transformation, leading it to become somewhat more acceptable. Some of the radical edge is gone from both the rhetoric and the intellectual positions of the people who identify themselves with cls. Although this has occurred in part because of the changing age structure of the group, and is related to questions of recruitment that I discuss in Part V, I should note (or confess) that I have detected some blurring of the edges in my own work. Although I would like to think this results from maturation and reflection, I am not sure that it does; it may just be a sort of Sartrean bad faith on my part. See also infra note 53 .

31. See supra note 10 (discussing significance of term "crits").

32. Sometimes the redbaiting is not so genteel, as when it is suggested that the logical implication of some cls position is identical to the political program of the Khmer Rouge. I would have thought that opponents of cls would understand that, given the indeterminacy thesis, cls adherents would probably not be embarrassed by such an argument. The indeterminacy thesis, in a suitably weak version, is precisely that there are no particular large-scale logical entailments of abstractly stated political prescriptions. If some position attributed to cls implies the political program of the Khmer Rouge, it also implies whatever utopian or practical political program the critic of cls wishes to advance. See also supra note 21.

33. For a recent example of this anti-intellectualism, notable oniy for its venue, see Lasson, Scholarship Amok: Excesses in the Pursuit of Truth and Tenure, 103 HARV. L. REV. 926 (1990). It is worth recalling the difficulty law and economics scholars had in getting the legal academy to take their work seriously at the outset, and the continuing anti-intellectual dismissal of the "graphs and numbers" aspects of law and economics work. 
the situation overall, ${ }^{34}$ though, cls is here to stay. I consider what that means in Part V.

\section{The EnLightenMient}

The origins of critical legal studies as a political location are relatively easy to identify. ${ }^{35}$ In early 1976 David Trubek returned from a trip to Cambridge and told me that he had spoken with Duncan Kennedy. They had agreed that there were a number of people doing academic studies of law that seemed to have certain common themes, and that it might be useful to gather these people, and a few others, to see whether that perception was accurate. The themes dealt with questions of ideology in ways that seemed compatible with the traditional focus on "law and society" at the University of Wisconsin Law School, yet concentrated on legal doctrine in ways that seemed compatible with more mainstream approaches to legal scholarship. If that perception were correct, the thought was, some sort of organizational locus for that intellectual work would be useful. Though the work had come to the attention of Kennedy, it was being done by people scattered throughout the country, often with no sense that anyone other than Kennedy might be interested in it or might make helpful comments on it. In addition, of course, there was the possibility (quickly realized once the organization got off the ground) that there were people doing similar work who had not sent it to Kennedy but who would want to affiliate with a group of sympathetic scholars.

I was then serving as Associate Dean at Wisconsin, and had a certain amount of excess energy - and the soul of a bureaucrat-which made it appropriate for me to do most of the organizational work attendant to putting on an academic conference. Even at the start there was some sense that a relatively formal structure was needed to provide the location for the academic activities that Trubek had referred to, and we developed a list of "steering committee" members to put on the letterhead.

The intellectual themes in the work that drew people together have now become standard lines about critical legal studies. Describing the political history of cls requires that those themes be identified at this point, but, as is common in overviews of cls ${ }^{36} \mathrm{I}$ must indicate at the outset that I will not be describing "tenets" of cls or dogmas to which one must adhere in order that one's self-identification with cls be accepted by others who similarly self-

34. By which I mean that individuals associated with cls are likely to face rather more trauma in hiring and tenuring than people not so associated, and may end up "underrecognized." For a discussion of this issue, see infra text accompanying notes 99-101.

35. I rely here primarily on my own recollection, checked by some conversations with others associated with the early days of cls. I am notorious in my family, however, for not remembering things very well. For another account of the origins of cls, see Schlegel, Notes Toward an Intimate, Opinionated, and Affectionate History of the Conference on Critical Legal Studies, 36 STAN. L. REV. 391 (1984).

36. See, e.g., M. Kelman, A GUDE to CRTtiCal Legal Studies 2 (1987). 
identify. There are at best family resemblances among various versions of these themes, and, as a matter of intellectual integrity, adherents of each version will criticize other versions for their intellectual shortcomings. Yet it turns out that the existence of the family resemblances may be the most important dimension of the work.

One characteristic of the work to which Kennedy and Trubek referred was the identification, in numerous substantive areas of law, of paired oppositions and standard arguments deploying sets of claims from one side of those oppositions against sets drawn from the other side. ${ }^{37}$ Deriving from the work of the legal realists, this technique led, in the first instance, to the development of the "indeterminacy" argument. As it was derived from the analysis of paired oppositions, the indeterminacy argument held that within the standard resources of legal argument were the materials for reaching sharply contrasting results in particular instances. Those results, it appeared, were exactly what people arguing directly over moral or political goals were seeking. Later this technique mutated into philosophically more sophisticated deconstructionist techniques, ${ }^{38}$ but adherents of cls continue to hold to the general perception that there is no interesting difference between legal discourse and ordinary moral and political discourse.

As we saw it, the legal realist versions of this technique had led some of the realists to offer a relatively informal descriptive and normative sociology of law. ${ }^{39}$ Descriptively, the existence of a community of lawyers, sharing what Llewellyn called a "situation sense," eliminated the possibility that contradictory results, available as a matter of theory, would actually be realized in practice. ${ }^{40}$ Normatively, the values of that community, or some other community into which it could be transformed, justified the choices among possible results at which the legal system arrived. The law and society tradition, with which Trubek and I were particularly sympathetic, had attempted to provide a more systematic basis for the realists' informal sociology of law. Some in that tradition, however, were more skeptical of the normative acceptability of the results found acceptable by the community of lawyers. A second theme in the work to which Kennedy and Trubek referred, then, was a critique of the sociology of law that was implicit in the way legal realism had been assimilated in the legal academy.

37. CRITICAL Legal STUdies (A. Hutchinson ed. 1989), described by one reviewer as "easily the best introduction to the 'mainstream' of CLS," Book Note, 100 ETHICS 912, 912 (1990), includes excerpts in this vein from R. UNGER, KNOWLEDGE AND POLITICs (1975), and Kennedy, Form and Substance in Private Law Adjudication, 89 HARV. L. REV. 1685 (1976).

38. See, e.g., Balkin, Deconstructive Practice and Legal Theory, 96 YALE L.J. 743 (1987); Dalton, An Essay in the Deconstruction of Contract Doctrine, 94 YALE L.J. 999 (1985).

39. Other realists moved in the direction of positivist policy science. See, e.g., Lasswell \& McDougal, Legal Education and Public Policy: Professional Training in the Public Interest, 52 YALE L.J. 203 (1943). Positivism had little influence on the development of critical legal studies, and positivist Marxism rapidly became marginalized within cls.

40. K. LLEWELLYN, THE COMMON LAW TRADITION 260-61 (1960). 
The critique drew upon the work of Weber and Marx, and a great deal of the early work associated with critical legal studies involved efforts to make sense of a Marxist-Weberian notion of the relative autonomy of law. ${ }^{41}$ There were latent tensions in these efforts. For some, Marxism was attractive because it argued against the inevitability of the permanent triumph of the capitalist system. Yet, while it was in that sense liberating, the strains of historical determinism in Marxist thought were in another sense confining. And of course, Weber's sociology, with its emphasis on the "iron cage" of rationality in bureaucratic societies, had an even more pessimistic message. ${ }^{42}$ The culturalradical strand in cls contributed an additional impetus to the forces emphasizing freedom of choice rather than determinism, while the continuing influence of the Marxist-Weberian tradition allowed cls to incorporate concern for what Unger has called "formative contexts" into the movement's intellectual work. ${ }^{43}$ This combination of elements, though, is not tidy, and causes obvious intellectual tensions, if not within individual adherents of cls then within the body of work called critical legal studies as a whole. These tensions, in turn, provide opportunities for critics of cls to challenge the coherence of the movement's intellectualized program.

Another dimension of the tensions within early cls work was that the efforts to develop a notion of relative autonomy repeatedly ran up against what many took to be the epistemological implications of the analysis of legal texts. In part because we were dealing with legal texts, and legal doctrines in particular, and because in dealing with those texts and doctrines we had come to see the existence of paired oppositions as central to the phenomenon being analyzed, the critique of the sociology of law directed attention to problems of ideology and consciousness. ${ }^{44}$ Somehow the community of lawyers resolved the contradictions expressed by the paired oppositions in a way that seemed to them normatively acceptable.

Once the work focused on normativity as a social phenomenon, it could draw into the domain of critical legal sociology the fact (if it was a fact) that to some people the resolution of the contradictions did not seem at all acceptable. The critique of the sociology of law thus led to the issue of alienation from, or as expressed within, the legal system. ${ }^{45}$ This critique was reinforced

41. See, e.g., R. UNGER, LAW IN MODERN SOCIETY (1976); Klare, Law-Making as Praxis, 40 TELoS 123 (1979).

42. For a discussion of Weber's analysis of rationality in the modern era, see A. MITZMAN, THE IRON CAGE: AN HISTORICAL INTERPRETATION OF MAX WEBER (1970).

43. See R. UNGER, SOCLAL THEORY: ITS SITUATION AND ITS TASK 88-89 (1987).

44. My contributions to this discussion were Tushnet, Perspectives on the Development of American Law: A Critical Review of Friedman's A History of American Law, 1977 WIs. L. REV. 81; Tushnet, $A$ Marxist Analysis of American Law, I MARXIST PERSP. 96 (1978).

45. At roughly the same time a communitarian critique of adjudication, in the form of advocacy of alternative dispute resolution mechanisms, became prominent in the law and society community. See, e.g., Menkel-Meadow, Portia in a Different Voice: Speculations on a Women's Lawyering Process, 1 BERKELEY WOMEN'S L.J. 39 (1985). 
by the cultural-radical strand of cls, which presented the experience of law as oppressive and alienating rather than as a normatively attractive solution to problems of social coordination. ${ }^{46}$

These themes converged in the programmatic statement that law is politics, all the way down. Most people in the legal academy agree, albeit often with some reluctance, that law is politics in the superficial sense that we can talk about identifiably liberal and conservative positions on various issues in the law, ranging from affirmative action to strict liability versus negligence. The indeterminacy argument and the critique of social theory led cls to a different understanding of the proposition that law is politics. We saw law as a form of human activity in which political conflicts were worked out in ways that contributed to the stability of the social order ("legitimation") in part by constituting personality and social institutions in ways that came to seem natural. The legitimating and constitutive operation of law occurred on all levels. Categories of legal analysis that underlay particular doctrines had, as we saw it, both kinds of effects. ${ }^{47}$ The concept of "reasonableness" used in tort law is political in the sense that it implicitly and sometimes explicitly relies on images of male behavior to define the norm of reasonableness. The related concept of "rationality" was politically defined to justify the expansion of European states into regions occupied by other peoples. In the end, adherents of cls argue that the entire notion of "the rule of law" and associated distinctions between objectivity and subjectivity incorporated a partial, and therefore political, definition of rational behavior.

Attempting to combine the analysis of paired oppositions in legal doctrine with a critique of the sociology of law led to a number of intellectual and political tensions. First, the sociology of consciousness available within the law and society tradition was severely underdeveloped. Second, any sociology of

46. The cultural-radical strand also influenced the organizational structure of cls, particularly through its emphasis on overcoming alienation through personal contact and its opposition to reified forms of democracy that reproduce the alienation of law as false community. My sense is that the emphasis on personal contact as a medium for organizational growth was particularly attractive to some of the early organizers because it meant that they could engage in a form of intellectual seduction that had powerful sexual overtones. For a literary version of the point, see A. BERNAYS, PROFESSOR ROMEO (1988), which, however, is not quite on point because the sexualization of intellectual seduction is apparent on the surface (and the book is less insightful as a result). For Kennedy's analysis, see Kennedy, Psycho-Social CLS: $A$ Comment on the Cardozo Symposium, 6 CARDOzo L. REV. 1013 (1985); for a response, see West, Deconstructing the CLS-Fem Split, 2 WIS. WOMEN's L.J. 85 (1986). Both of these focus on the psychology of male-fernale relations; my sense is that the intellectual seduction of men combines homoeroticism, projection, and envy as the seduced males imagine themselves in the place of their seducers.

47. The most noteworthy discussions occurred in connection with the distinction between the public sphere and the private sphere. See The Public/Private Distinction, 130 U. PA. L. REV. 1289 (1982). The phenomenon occurs, however, on less exalted levels, as when workplace injuries are conceptualized initially on the model of having a hand crushed in a press, then reconceptualized as including environmental harms such as asbestos in the workplace and, later, environmental harms such as sexual and racial harassment in the workplace, but not yet as including the "ordinary" depletion of human capital attendant upon working on an assembly line. For an example drawn from outside the cls literature, see Asch, Wildlife: Defining the Animals of the Dene Hunt and the Settlement of Aboriginal Rights Claims, 15 CANADIAN PUB. POL'Y 205 (1989) (analyzing use of terms "wildlife" and "domesticated animals" in treaties and native discourse). 
consciousness, when developed beyond the rudiments, was likely to be in some tension with what we took to be the leanings toward determinacy that characterized the main tradition of Marx and Weber. ${ }^{48}$ Third, it seemed unlikely at the outset that whatever sociology of consciousness we could develop would describe any serious connection between the legal doctrine that was the focus of the first theme in the work and the concern for consciousness that was the focus of the second theme. Most of the work either stated or suggested that the legal doctrines we studied somehow "legitimated" the legal system, but did not fully explain how. The only mechanism of legitimacy we talked about was a sort of "transmission belt" theory of legitimacy. Under this theory, legal elites articulated fancy theories about why and how the existing system was the only really effective way to advance all sorts of human goods, and then sold those theories to publicists in the mass media, who transmitted suitably watered-down versions to the general public, which accepted the theories as completely sensible. This theory seemed unlikely to be sufficient in the end. ${ }^{49}$

Finally, there was a latent tension between the cultural-radical perception of law as alienating and oppressive and the political location of cls adherents as sometime participants in political activity on the side of the oppressed. The tension, made manifest in the minority and feminist critiques of some presentations of cls positions, was that for many of the oppressed the experience of the law was both alienating and liberating, sometimes simultaneously and sometimes in succession. ${ }^{50}$

More important than these difficulties, however, were what we took to be the implications of the analysis of indeterminacy for social theory itself. ${ }^{51}$ Classical social theory had not paid much attention to questions of law, yet legal terms - in particular, "ownership of private property"-played a large role in the fundamental structure of Marxist and, to a lesser extent, Weberian social thought. If those terms were, as we believed them to be, indeterminate, the conclusions of classical social theory regarding the inevitable triumph of the working class or of the "iron cage" of bureaucratic society rested on sand. ${ }^{52}$ In short, the indeterminacy thesis threatened the social theory that legal realists had relied on to resolve the normative and descriptive difficulties exposed by their analysis of law. Put a different way, the indeterminacy thesis, developed

48. I use the locution "took to be," and similar ones, to make it clear that I am offering an intellectual history of cls at this point, not an exegesis of classical social theory.

49. Methods of social investigation that were different from those used in the law and society tradition, including introspection and personal narratives, have been used in cls as elsewhere. In my view, however, these methods remain less developed than necessary to provide full support for the central proposition that law legitimates and constitutes society.

50. See, e.g., Minority Critiques of the Critical Legal Studies Movement, supra note 25.

51. Here it is easier for me to switch from the language of "paired oppositions" to the language of "indeterminacy," though my sense is that the latter language emerged after the points made in the text became common currency in cls.

52. For some, this line of thought was reinforced by their acquaintance with the work of Karl Polanyi. See K. POLANYI, THE GREAT TRANSFORMATION (1944). For me, the most important article was Samuels, Interrelations Between Legal and Economic Processes, 14 J.L. \& ECON. 435 (1971). 
in the specific context of legal doctrine, created an atmosphere in which the deterministic leanings of classical social theory were suspect. ${ }^{53}$

The critique of social theory also had a political dimension. The determinism that we imputed to classical social theory was inconsistent with our understanding of the social movements in the United States for civil rights and against the war in Vietnam, movements in which moralistic consciousness patently played a larger role than we believed classical social theory could account for. The critique of rights, and the criticisms of that critique discussed earlier, are efforts within critical legal studies to develop a sociology of legal consciousness that more adequately accounts for moralistic liberation movements than the "transmission belt" model of legitimation. Further, the determinism we found in classical social theory seemed to us to have a demobilizing effect in the circumstances of the mid-1970's, when the liberal reformist impulses associated in law with the Warren Court appeared to have played themselves out. By bringing questions of consciousness and alienation to the fore, the cls approach might contribute to the development of a social theory that need not be demobilizing in adverse political conditions. At the same time, however, the critique of social theory fit awkwardly with the educated intuitions of many politically active lawyers who associated with cls. They accepted an informal Marxist account of law and society, in which one could explain legal outcomes most of the time by referring to the interests of the ruling class. The critique of social theory threatened that understanding of the legal order, and to the extent that activist lawyers had been able to account for their activity by locating it with reference to that understanding, the critique of social theory called their activities into question. ${ }^{54}$

The combination of the analysis of paired oppositions with the critique of social theory itself created political difficulties for cls. I have described an intellectual program that has a certain degree of coherence, but few people associated with cls at the outset thought that each element in the program was as important as the others, and many who agreed with some parts of the program were uncomfortable with others. The family resemblance among the works that initially identified themselves with cls was their political orientation on the Left. The Left, though, is hardly a narrow terrain itself, and political differences within the Left sometimes were associated with intellectual differ-

53. In this connection, the implications of postmodernism as a critique of all totalizing theories seem particularly important. To the extent that postmodernism supports a form of pluralism-theories that offer local solutions without making grander claims-it seems consistent with the political practice of cls. Iremain uneasy about whether a postmodernist can hold a leftist political position, even as I acknowledge that the "can" in that statement itself suggests that I have not fully assimilated the postmodernist lesson.

54. To the best of my recollection, the standard critique of Marxist determinism-that because the engine of history ran in the direction of the triumph of the working class, deliberate action was unnecessary-did not play an important part in early cls thinking. 
ences over elements in the cls "program." 55 In particular, the implicit "transmission belt" social theory, which linked our attention to mandarin legal texts $^{56}$ with social transformation or legitimacy, was implausible; yet it was associated with the critique of social theory, which might be tainted by the association. People on the Left, that is, could still have an image of a mobilized working class as the vehicle of social transformation, propelled by changes in the technical relations of production. ${ }^{57}$ This counter-image of social theory led to tensions within cls about the appropriate form of our organization. Some believed that a left-wing political organization had to make some effort to connect with other political organizations on the Left, and that the theoretical work was basically useless for left-wing politics. Others believed that the theoretical project was interesting enough, and difficult enough, that internal development was more important, and that attempts to expand the scope of the organization were likely to cause even more political difficulties as the degree of internal political homogeneity (already low enough to cause political problems) would inevitably diminish.

The solution turned out to result from what I see as Duncan Kennedy's political judgment and my bureaucratic mentality. For Kennedy, it was more important to sustain cls as a political location for people who found such a selfidentification valuable than to adopt a particular organizational stance. Further, he and others in the core group of early cls believed that the political conflicts

55. I doubt that there are tight conceptual connections between the political positions and the intellectual ones; indeed, my guess is that the best account of the association would be sociological and psychological. An important element, for example, seems to me a deep ambivalence about the obviously important role that has been played by people who teach at Harvard Law School. The ambivalence is that people either have mentors at Harvard or understand that a strong cls presence there provides some validation for their own efforts, and yet they correctly believe that the position of Harvard in the legal academy is an example of illegitimate hierarchy. This ambivalence affects the degree to which people on the Left differentiate themselves intellectually from others on the Left.

I suppose that a comment about my own position, as I see it, is appropriate at this point. I attended elite institutions, including Yale Law School, and had a prestigious judicial clerkship. But my grades at Yale were not that good, so I did not receive the kind of institutional blessing that attends the "superstars," and I marginalized myself/was marginalized by being identified as a Marxist, by playing a prominent role in the organizational structure of cls, and by being nasty in print to people who, according to the standards of hierarchy, deserved better treatment. Further, when cls got started, I was teaching at the University of Wisconsin Law School, which occupies a peculiar place in the hierarchy of the legal academy, and now teach at Georgetown, which, as far as I can tell, occupies no particular place at all in that hierarchy. My sense is that, as a result of all this, I am what anthropologists call a "liminal" figure, who is allowed to operate between institutions with a certain facility that, according to the anthropologists, may yield deep insights (on the part of the anthropologist, not the liminal figure, I hasten to add) into the operation of the institutions. I should say that I remain somewhat puzzled about my role in the internal politics of cls, particularly because I have not done much more, since the mid-1980's, than write articles. I am reasonably sure-and annoyed-that externally I am seen as a safe ambassador from cls to the mainstream.

56. The phrase is drawn from Gordon, Critical Legal Histories, 36 STAN. L. REV. 57, 120 (1984). For what it is worth, my view is that Gordon's response to criticism of attention to these texts is not completely successful.

57. For reasons that I do not understand, the challenge to cls from the traditional Left has not picked up on G.A. Cohen's rehabilitation of classical Marxist theory. See G.A. COHEN, KARL MARX'S THEORY OF HISTORY (1978), discussed (sympathetically) in Tushnet, Book Review, 68 CORNELL L. REV. 281, 285-86 (1983). 
were more apparent than real, and that when people actually got down to the business of doing something they would discover that their common political orientation was more important to them than their political disagreements. For me, being a bureaucrat meant getting the job done: maintaining the mailing list, making sure there were newsletters sent out, helping people who wanted to put on events get on with the job. I do not claim to have thought through the political significance of being a bureaucrat in this context, but it turned out that getting the job done is pretty much what cls needed at that point. For cls as a political location, what mattered was not getting the intellectual line right, though because we were located primarily in the academy we did have to do intellectually interesting work. What mattered was keeping the location available to people who needed it..$^{58}$

In the years after the location was established, it moved like an amoeba over the landscape of the Left in the legal academy. It extended to new constituencies, absorbed some and rejected others after an initial flirtation, and extruded a very few who had initially been associated with cls. In the process the location was transformed, as strands within the location found themselves located somewhat differently with respect to the group as a whole: marginalized or in the center, after having been in the center or on the margins. Through all this, the occupants of the location continued to influence each other, though not without some strain..$^{59}$

\section{THE DARK AgeS}

In the late 1960's and early 1970's the faculty of Yale Law School fired six professors. ${ }^{60}$ The Official Story is that the faculty had decided to raise the standards for granting tenure. The real story is somewhat different. ${ }^{61}$

58. One indication of the role of cls as a political location is the rather rapid falling away of people like George Fletcher who, though interested in the analysis of paired oppositions, did not share the political orientation that characterized cls as a political location.

59. Because my focus in this Article is on the external politics of critical legal studies, I will not examine the largely internal political history of the process by which the location transformed itself.

60. Richard Abel, Lee Albert, John Griffiths, Robert Hudec, Larry Simon, and David Trubek. I know of no other sequence of such concentrated firings. The firings at Harvard Law School of Dan Tarullo and Clare Dalton, coupled with President Derek Bok's refusal to agree to the law faculty's recommendation that David Trubek (again) be appointed to the faculty, have not (yet) reached a similar level of intensity. In 198687 four people were fired at the New England School of Law, at least in part because of a perception that they were associated with critical legal studies.

61. Calling what follows the real story can be defended in two ways. The weaselly way is to say that I am recounting the events as they were interpreted within cls, not as they "really" happened. The other way is to begin by noting that the publication records of people promoted from within at Yale in the years after the firings did not materially differ from those of the people who were fired at the time they were fired. The next step is to explain that fact in the face of the Official Story. One possibility is that the number of internal promotions was small, and the publication records lay at the tail of a distribution which, when fully understood, centers around a higher tenure standard. Another is that the faculty, after coming to understand the costs of firing people, simply changed its mind. A third is that the faculty indeed raised the tenure standard in the sense of demanding of itself a much firmer predictive judgment about future scholarship than it had used in the 1960's, and that the post-tenure publication records of internal promotions, while 
New Haven at that period was a city in substantial turmoil. Leaders of the Black Panther Party were being prosecuted for murder in a case that attracted national attention. The Yale campus experienced the usual disruptions resulting from protests against the war in Vietnam, made somewhat more prominent perhaps by the presence of William Sloane Coffin at the University. ${ }^{62}$ The cultural radicalism of the period led students to engage in flamboyant dress and behavior. The Yale Law School student body was not immune from these influences, even cultural radicalism, which in turn affected the faculty at the Law School. ${ }^{63}$ The faculty had invested a great deal in developing a sense of itself as "the best and the brightest" of a generation of policy-oriented legal intellectuals. ${ }^{64}$ What seemed to them a flamboyant cultural radicalism constituted a direct rejection of principles to which the faculty were devoted at the core of their being.

The faculty of the Law School meanwhile had undergone a significant expansion at the junior level, and the younger faculty became tainted by the mere presence of students who were only a bit younger. In addition, though few of the junior faculty had radical politics, they were all substantially more sympathetic to the claims being made by students than were many of the senior faculty. The senior faculty took on the air of a beleaguered garrison, defending the ramparts at all costs against the assaults of the barbarians. Those who suggested even in the mildest way that the students might be on to something were politically unreliable. Under the circumstances, any disagreement threatened the institutional stability to which many of the senior faculty were dedicated.

The political disagreements between the junior faculty and the majority of the senior faculty were, in the larger scheme of things, relatively minor. John Griffiths helped set up a legal research seminar on problems arising from the draft, and conducted empirical research on the effectiveness of the Miranda warnings ${ }^{65}$ given by federal agents investigating draft evasion. ${ }^{66}$ Understandably, he did not turn in his draft card. No faculty member, as far as I can recall,

thin, are still too recently compiled to disconfirm those judgments. (To pull this one off, though, one would also have to concede that, as to a fair number of those fired, the faculty's predictive judgment about future scholarship was simply dreadful.) My view is that none of these explanations of the similar records of people promoted after the firings and those who were fired comes close to plausibility.

62. Coffin, a minister, was among those indicted for antiwar activities. For an account of the trial, see J. MITFORD, THE TRIAL OF DR. SPOCK (1969).

63. A "commune" was established in the courtyand of the Law School, though by national standards it was a relatively tame affair.

64. I am reasonably confident that I believed the faculty and people like them to be indeed "the best and the brightest," according to the standards developed by their community. Thus, when that phrase was used to describe the generation that got the nation involved in the Vietnam War, as in D. HALBERSTAM, THE BEST AND THE BRIGHTEST (1972), I took it to be a criticism of those standards rather than of the people. That view has, I think, permanently affected my position on questions of meritocracy in law school politics.

65. See Miranda v. Arizona, 384 U.S. 436 (1966).

66. See Griffiths \& Ayres, A Postscript to the Miranda Project: Interrogation of Draft Protestors, 77 YALE L.J. 300 (1967). 
joined that segment of the student body arguing in favor of terminating the Panther prosecution, though I remember Larry Simon expressing some misgivings about the way the rhetoric of "the rule of law" was being deployed to support the prosecution. ${ }^{67}$ Yet these minor political disagreements demonstrated that the junior faculty were "unsound."

To many of the senior faculty, the junior faculty's lack of judgment was demonstrated as well by their scholarship. Richard Abel was positively uninterested in doctrinal scholarship of any sort. Griffiths did a certain type of doctrinal scholarship, but not one that the senior faculty was comfortable with. Griffiths' major work, prior to his firing, amounted to a powerful assault on the prevailing view in criminal law scholarship, developed by Herbert Packer, that society faced a choice between a "due process" model and a "crime control" model..$^{68}$ Griffiths argued that Packer had identified only a single model of the criminal process; Griffiths offered instead what he called, necessarily but misleadingly, a "third" model, which today would be viewed as an interesting communitarian-feminist approach to criminal procedure but which then was seen as wildly totalitarian. ${ }^{69}$ In many ways the reaction to Griffiths' articles can be understood as a model of the whole process. Not only were they severely critical of what many on the senior faculty regarded as the culmination of a life's work by a major figure in the field; they also had a tone suggesting that Griffiths could not believe that anyone with an ounce of intellectual integrity could take Packer's work seriously, let alone write it. Even worse, they were published almost contemporaneously with the massive stroke that ultimately led Packer to commit suicide. ${ }^{70}$ If Griffiths didn't exactly cause the stroke, for the senior faculty his behavior-which his hypercritical tone exemplified-was typical of the sort of thing that led men of their generation to have strokes.

Griffiths' scholarship was symptomatic in another way. Most of the senior faculty had absorbed the New Deal understanding of legal realism. In that understanding, symbolized by the work of Myres McDougal, the indeterminacy of formalistic legal rules should be replaced by a form of policy science that drew informally upon the wisdom of the social sciences to inform legal judgment. Social science would be called upon to answer questions that lawyers found interesting as they attempted to resolve conflicts that formalism left unresolved. Taking the standard line at Yale Law School more seriously than

67. For additional discussion, see infra text accompanying notes 76-78. I use the examples of Griffiths and Simon precisely because they have not subsequently been closely associated (to put it mildly) with critical legal studies.

68. See Packer, Two Models of the Criminal Process, 113 U. PA. L. REV. 1 (1964).

69. See Griffiths, Ideology in Criminal Procedure, or a Third "Model" of the Criminal Process, 79 YALE L.J. 359 (1970); Griffiths, The Limits of Criminal Law Scholarship, 79 YALE L.J. 1388 (1970).

70. See Seltzer, Herbert L. Packer, 26 STAN. L. REV. 997, 999-1000 (1974) (mentioning Packer's stroke in late 1960's and alluding to his suicide in 1972); see also Gewirtz, A Lowyer's Death, 100 HARV. L. REV. 2053 (1987) (on our inability to confront the fact that people commit suicide). 
its purveyors did, ${ }^{71}$ the junior faculty went back to the roots of legal realism and found them more radical than legal realism appeared to be in the New Deal understanding. David Trubek co-authored an article with Judge Charles Clark, arguing that Karl Llewellyn's late work betrayed the fundamental insights of earlier legal realism. ${ }^{72}$ For them, Llewellyn had reinscribed formalism in law by locating it in the "situation sense" of the lawyering class. ${ }^{73}$ If, as I have noted, "situation sense" was a socially constructed phenomenon, it could be investigated by the techniques of social science. Now, however, social science would not be merely instrumental to policymaking; rather, it would be a true science of law as a social phenomenon.

Trubek and Abel in particular turned to classical social theory for their understanding of that phenomenon. ${ }^{74}$ In conjunction with a program in law and development generously funded by the Agency for International Development, they instituted a reading group on the philosophy of social science undergirding a social theory of law, in which Duncan Kennedy, Nancy Gertner, Helene Ietswaart, and several others, including myself, participated. This association with student radicals, even a fairly intellectual association with fairly intellectual student radicals, did them no good in the eyes of the senior faculty. And, in some sense, rightly so. For, in the course of these discussions, shaped by the confrontation of legal realism with classical social theory in a climate of political confrontation, the outlines of what became critical legal studies were sketched. $^{75}$

The moralism of the oppositional politics of the Dark Ages also deserves emphasis. Student discontent with the course of public policy led many of us to reject the role that had become central to the image of lawyering at Yale Law School: the well-meaning public servant interested in influencing the course of public policy by providing informed judgments about what marginal changes in policy would advance the goal of social justice. Part of the draft resistance movement, quite strong in the Yale community, was purely moralistic in its rejectionism. With a Yale Law School education, I could not fail to

71. See R. UNGer, THE CRTTICAL LEgal StUdies MOVEMENT 119 (1986) ("Having failed to persuade themselves of all but the most equivocal versions of the inherited creed, they nevertheless clung to its implications and brazenly advertised their own failure as the triumph of worldly wisdom over intellectual and political enthusiasm.").

72. Clark \& Trubek, The Creative Role of the Judge: Restraint and Freedom in the Common Law Tradition, 71 YALE L.J. 255 (1961).

73. See supra note $\mathbf{4 0}$ and accompanying text.

74. See, e.g., Abel, Law Books and Books About Law (Book Review), 26 STAN. L. REV. 175 (1973); Trubek, Toward a Social Theory of Law: An Essay on the Study of Law and Development, 82 YALE L.J. 1 (1972).

75. The long-term effect of these events on the intellectual atmosphere of the Yale law faculty deserves a note. Overall, they seem to have led the faculty to adopt a form of self-presentation that, curiously, combines Star Trek with Marathon Man: asserting that they are boldly going where no one has gone before, all the while looking over their shoulders nervously and asking, "Is it safe?" (The point at which the metaphor breaks down will be clear to those familiar with Marathon Man, and explaining to others why it breaks down at that point would compound the difficulty.) 
experience substantial cognitive dissonance when my roommate, outraged at the immorality of the war, framed his outrage in legalistic terms. Sharing his outrage, my only course, really, was to reject his legalism.

For a variety of reasons, I was only a peripheral member of the reading group and the law-and-development community at Yale. It took me a long time to grasp the point of legal realism, which eventually came home to me in a seminar on law and psychiatry co-taught by Jan Deutsch and Jay Katz. Having got it, I produced what in retrospect seems to me my first cls argument. Protests over the Panther trial led to a "town hall" meeting of the Law School community. The predominant rhetoric was that the Panthers, having been lawfully indicted on the basis of what all conceded was probable cause, should be subject to the regular process of the law, which should go forward to its regular conclusion: a trial, a verdict, and, if necessary, an appeal. At that meeting I made the following argument, a version, I now think, of the indeterminacy argument. Crucial evidence leading to the indictment of the Panthers had been seized during a full-scale search of a house incident to an arrest. At the time of trial, such a search would have been unconstitutional and the evidence could not have been used against the Panthers. ${ }^{76}$ The Supreme Court had recently held, however, that the prohibition against such searches would not be applied retroactively. ${ }^{77}$ Thus it would not violate any constitutional rule enforced by the courts to use the illegally seized evidence against the Panthers. Yet, I argued, it would not be inconsistent with the rule of law for a prosecutor to determine, as an exercise of discretion, that it would nonetheless be inappropriate to use that evidence. Thus I concluded that nothing in the rule of law required that the trial go forward to verdict and beyond. Although it needs cleaning up, I still think it's a good argument. ${ }^{78}$

\section{PREHSTORY}

The standard account of the origins of cls includes a reference to the influence of the civil rights movement and the Warren Court on the motivations of left-leaning lawyers and academics who were attracted to cls. ${ }^{79}$ In this account, the experience of the Warren Court and its interaction with the civil

76. See Chimel v. California, 395 U.S. 752 (1969).

77. See Hill v. California, 401 U.S. 797 (1971); Williams v. United States, 401 U.S. 646 (1971).

78. Today I would stress, in addition to discretion, the possibility that the prosecutor's oath of office required him to arrive at an independent judgment on the constitutionality of using the evidence, as well as the possibility (which cuts both ways) that the prosecutor's duty to enforce the law-the Constitution as well as the law against murder-supports a decision to forgo prosecution based on illegally seized evidence. (The argument, of course, goes to the coherence of the "rule of law" position that was being articulated to justify continuing the Panther trial. It would not be effective against other arguments, most notably that the Panthers were in fact guilty. Still, though I believe that many people did think the Panthers were guilty, almost none of the rhetoric around the trial dealt with that question, perhaps because that would have opened up directly the question of whether the trial was or was not political in the classic sense.)

79. See, e.g., Binder, On Critical Legal Studies as Guerrilla Warfare, 76 GEo. L.J. 1, 13-24 (1987); Schlegel, supra note 35, at 406-07. 
rights movement convinced us that, notwithstanding the skeptical determinism associated with Marxist social theory, it was possible for law to become an autonomous force for progressive social change. In developing the critique of social theory and the indeterminacy thesis, we attempted to provide a theoretical grounding for our political inclinations.

Without minimizing the explanatory power of that account, I think it worth noting another strand that worked its way into cls. A fair number of the first group associated with cls were "red-diaper babies," the children of leftist activists in the 1930's and thereafter. ${ }^{80}$ The formative legal experience for this group, I believe, was the law's half-hearted defense of civil liberties against McCarthyism, not the civil rights movement; the paradigmatic judge was Irving Kaufman, not Earl Warren. Yet such an experience and such a paradigm could hardly generate real enthusiasm for the law as an instrument for progressive change.

It is probably best here to work through my understanding of how that experience played itself out for me. When my parents were called to testify before the House Committee on Un-American Activities, the Fifth Amendment became a living thing in our household. I read and was invigorated by Dean Griswold's The Fifth Amendment Today. ${ }^{81}$ For all its inspirational defense of the privilege against self-incrimination in the McCarthy era, however, the book ultimately rang a little hollow. While the experience was hardly welcome, my parents suffered no legal sanctions, and few social ones, as a result of their appearances.

Later, the legal system imposed more distress on the family. After the worst excesses of the period had ended, a former activist ran for the school board of Newark. The Newark Star-Ledger opposed her candidacy, and in an editorial referred to her as "a dope or a dupe" of the Communists. This being the era before New York Times Co. v. Sullivan, ${ }^{82}$ she sued the paper for libel..$^{83} \mathrm{My}$ parents and many of their friends were sucked into this lawsuit, which revived all of the tensions that had been associated with McCarthyism. It was as if the law simply reached out to intrude on people's lives, with no good reason. Nor did "the law" appear in a good light when my mother gave her deposition. One issue in the lawsuit was whether the plaintiff should have known that Communists were present at a meeting in our house. The meeting had been held in our living room, and my mother was asked to describe the room, so that inferences

80. From this point on, I speak only of my own understanding and experience, not that of other reddiaper babies associated with cls; without additional evidence readers may find the account that follows too thin to be interesting, but providing additional detail seems to me akin to "outing" (the public identification of prominent gay people who have not chosen so to identify themselves) backed up by none of the political arguments that can be made in favor of outing.

81. E. GRISWOLD, THE FIFTH AMENDMENT TODAY (1955).

82. 376 U.S. 254 (1964).

83. For reported opinions of the case, see Nusbaum v. Newark Morning Ledger Co., 33 N.J. 419, 165 A.2d 177 (1960); Nusbaum v. Newark Morning Ledger Co., 86 N.J. Super. 132, 206 A.2d 185 (1965). 
could be drawn from the size of the room as to the likelihood that the plaintiff knew all the people there. My mother began by saying that there was a piano in the corner, with an accordion underneath, and continued in great detail until the point of the question was entirely lost. ${ }^{84}$

For me, then, the law was a slightly farcical enterprise. ${ }^{85} \mathrm{Why}$, then, was I interested in law? Perhaps the most important dimension is one that seems silly in retrospect. One reason that my family had been able to get through the McCarthy period relatively unscathed was that my father was a self-employed doctor. Such professionals, including lawyers as I saw it, were in a position to survive no matter what. The worst that could happen-and it did-was that a few patients might leave my father. But he was a very good doctor, and they knew it, which meant that they had to give up something valuable in order to implement their political views. Lawyers might be in the same position. In leftwing circles in the 1950's the image of the lawyer as an independent professional might have made enough sense to lead a young person to think it an attractive career. Everyone needed wills and the other kinds of general practice assistance provided by sole practitioners. By the time actual career decisions had to be made, of course, the structure of the profession and, probably more important, my own aspirations, had changed enough to make the image incongruent with my sense of my career. Undoubtedly, though, the image left its residue.

The law was attractive for another reason. If the powers that be are likely to go after dissidents, lawyers can provide some defensive assistance. Prior to the civil rights movement, in fact, Clarence Darrow was the iconic leftist lawyer. Darrow provided what the culture accepted as brilliant criminal defenses to victims of state oppression such as Dr. Ossian Sweet and John Scopes. ${ }^{86}$ On a lesser scale, the lawyers with whom my parents consulted provided essential support in a time of trouble.

If my self-understanding is accurate and the experiences that shaped it are typical of the red-diaper babies, our image of law probably was not all that bright. If cls developed a critique of law, it was therefore not entirely the result of disillusionment by the late-1970's defeat of the movement for large-scale social transformation through law-a defeat which was particularly agonizing after the initial successes of the civil rights and welfare rights movements in the 1960's and early 1970's. The red-diaper babies had never expected much

84. I remember the room as being quite large, but that may result from the phenomenon described in the folk-tale, "My Mommy Is the Most Beautiful Woman in the World." For a version of the story, see B. REYHER, MY MOTHER IS THE MOST BEAUTIFUL WOMAN IN THE WORLD (1945).

85. Ultimately, I suspect, it is this that linked the red-diaper babies, who typically had rather bourgeois attitudes about the proper forms of self-presentation, to the cultural radicals, who had rather different attitudes, but who articulated the alienation from and oppressiveness of law in a way that made sense to the red-diaper babies.

86. For the presentation of Darrow in popular culture, see I. STONE, CLARENCE DARROW FOR THE DEFENSE (1941). 
of the law anyway. Rather, our influence on the development of cls had two elements. Having seen how the law really worked in McCarthyism's impact on daily life, we were skeptical about claims for the efficacy of the law as an instrument of progressive change. In addition, our experience with the law made us sympathetic to the project of the law and society movement. In particular, we were attracted to the informal Marxism that was shared by many other lawyers, and that posed a counterweight to the development of the critique of social theory. ${ }^{87}$

\section{FUTURE HISTORY}

In imagining the future of critical legal studies, one must be hesitant, if only because the events of 1989 in China and central Europe seem to indicate that nobody knows anything about how societies actually operate. ${ }^{88}$ Alternatively, one might conclude that the cls critique of social theory was basically correct: no large-scale generalizations about how societies work are likely to have much to say about actual historical transformations. A standard question about cls, "Is cls more like law and economics or law and psychiatry?," inevitably calls for predictions in which no one can have much confidence.

Law and economics has settled into the legal academy, while law and psychiatry remains a marginal subdiscipline that has no substantial continuing vitality. As a political location, cls resembles the former more than it does the latter, but the political conditions for continuing support of cls may not persist. The new constituents for critical legal studies, conceived of as a political location, may be harder to come by in the future.

Those political conditions can be divided, for present purposes, into the intellectual vitality of cls and the political circumstances in which legal academics are likely to find themselves in the relatively near future. ${ }^{89}$ The intellectual program of cls may well have to be refocused, which may drain it of some vitality. In particular, the developments of 1989 rather strongly suggest that a leftist political movement may find it difficult to take comfort in the continuing effort to discredit classical social theory. To the extent that the critique of social theory relied on an image of self-willed action relatively independent of social circumstances, the events of 1989 are likely to generate a straightforward liberal idealist theory of social change rather than a more radical left-wing theory. To

87. It is probably not insignificant that $I$ was one of the red-diaper babies with these inclinations. By holding a position of some visibility within cls, I was able to suggest by my presence that the cls project was not completely idealist (as against materialist).

88. After those events one wonders about the utility of reading articles on the op-ed page. Certainly some commentators got it right, though probably not at a rate greater than one might expect from a group of monkeys at a typewriter. Perhaps one might read such articles, and indeed this one, for the insights they give not into developments in the world, but into the sensibility of their authors. (I, of course, have a vested interest in defending some version of the latter point.)

89. The intellectual vitality of cls is properly considered a political condition because cls is located in the academy and must therefore have a credible intellectual program for it to serve as a political location. 
sustain its intellectual and political force, then, cls may have to return to classical social theory, stressing the limits that social circumstances place on the accomplishment of substantial change while acknowledging that people do indeed, at least sometimes, make history with will and consciousness.

Such a return, however justified politically and (in my view) intellectually, may itself limit the intellectual and even the political vitality of cls. For, on one level, all that needs to be done is the rather boring job of establishing that nothing of any interest follows from "the triumph of capitalist democracy." The standard versions of legal realism are sufficient to make that point. And, to the extent that developments in Europe show that there is a large variety of political and economic choices that fit within the definition of "capitalist democracy" (including forms of social democracy that in other times would simply be called socialism), the return to social theory may itself be relatively uninteresting: choice may be somewhat constrained by social circumstances, but not in any particularly dramatic way.

Looking at the domestic situation, the intellectual program of cls may have its own weaknesses. The cls critique of legalism has, in my view, reached a point where it may be difficult to develop substantial political energy from its continuation. The point may be made by imagining that we have developed a measure of the determinacy of a set of legal rules, the "determinile." A completely determinate legal system would measure 100 determiniles, while a completely indeterminate one would measure zero. Cls adherents at present defend the position that the proper measure of legal systems is probably between five and fifteen; that is, no system is completely indeterminate, but the level of determinacy is relatively low. Mainstream legal theorists at present defend the position that the proper measure of well-functioning legal systems like that of the United States is somewhere between forty and sixty; that is, such systems have a substantial amount of indeterminacy, but not nearly as much as the cls position claims..$^{90}$ The positions differ, as is suggested by the existence of a gap between the "most determinate" version of the cls position and the "least determinate" one of the mainstream position. In addition, among cls adherents there is disagreement about the primary reason for the degree of determinacy that there is: power relations associated with gender differences, race differences, and class differences are all candidates of some. Yet at this point we are simply arguing over a mere detail, the question of degree. Such arguments are less likely to generate the kind of political heat generated by the more extreme versions of cls and mainstream positions during earlier phases of the discussion, and are less likely to lead left-leaning legal academics to the cls position.

90. For a forceful presentation of this position, see A. ALTMAN, CRITICAL LEGAL STUDIES: A LIBERAL CRITTQUE $90-98$ (1989). 
The assimilation of cls into the academy appears to have led to a general acceptance of a weak version of the position that law is politics, all the way down. For several reasons, the fact that the academy has accepted that version of the position may not lead to further accretions to cls. First, there remains resistance to the general proposition in its strongest form. At present, most of the force of the strong form-the "all the way down" part-is being carried by feminist and minority scholarship, not all of which is associated with cls.

Second, the academy has had difficulty understanding how people could be interested in the law without being interested in influencing policymakers. Yet, in light of the substantive political views associated with cls, that seems to be the case for cls. The concern of law schools with those presently holding power, or likely to do so in the near future, makes the more radical program associated with critical legal studies seem disconnected from the mission of the law school. ${ }^{91}$ People associated with cls have a different sense of where the real political action is, and have started to develop forms of legal theorizing and legal practice that orient themselves toward mobilizing communities for more than incremental change. Yet, from the point of view of recruitment to cls, the difficulty is that the legal academy is likely to continue to have a mainstream-liberal tilt. Because the opportunity costs of becoming a legal academic are higher for right-leaning potential academics, the academy is likely to continue to have a bias toward the Left. ${ }^{92}$ Yet, exactly what liberal law professors can do in an era in which the political Right dominates policymaking is unclear. The legal realist move toward positivist science has been discredited, for these academics, by attacks on positivism emerging from elsewhere in the academy, ${ }^{93}$ and, more important, by the appropriation of positivism by law and economics, with its rightward bias. ${ }^{94}$ At the least, the drift to the right in the legal academy is likely to be a bit slower than the move to the right in

91. Symptomatic is the common observation after the failed nomination of Judge Robert Bork to the Supreme Court that one lesson young legal academics might draw from the episode is to refrain from expressing potentially controversial views in their scholarship, lest they be caught up in a future nomination battle in which their writings would play a prominent role. See, e.g., Murray, Souter: Some Sad Lessons, NEWSWEEK, Sept. 24, 1990, at 15. A rational assessment of the probability that any young legal academic will be in a position to face such difficulties should lead to the conclusion that young academics who consciously alter their scholarship out of concern about its effect on nomination suffer from grandiose thinking of nearly clinical proportions.

92. That bias could be overcome were the values of the academy to change so that substantial consulting activities came to be viewed as positively valuable for the law school as an institution, reducing the gap in salaries between the academy and the kind of corporate practice to which right-leaning lawyers are differentially attracted.

93. The canned footnote here typically begins with T. KUHN, THE STRUCTURE OF SCIENTIFIC REVOLUTIONS (1970), and continues according to the author's taste and reading.

94. I do not deny the existence of a liberal form of law and economics. See, e.g., Rose-Ackerman, Law and Economics: Paradigm, Politics, or Philosophy, in LAW AND ECONOMICs 233 (N. Mercuro ed. 1989). That form may be better economics, because it introduces more complexity into the discussion. Yet precisely because it does so, the effort by right-wing law and economics to cloak its policy prescriptions in the mantle of science is unavailable to liberal law and economics. The liberal version of law and economics thereby does not appear to be substantially different from a fancy way of presenting its adherents' political judgments, reached largely independently of the economic analysis. 
social policy. ${ }^{95}$ As a result, the academy is likely to retain a place for cls, which can fill the vacuum left by the liberal academy's inability to figure out how to do liberal policy science in a conservative era. ${ }^{96}$

One might apply some aspects of the critique of rights to the situation of critical legal studies. The legal academy has accepted our scholarship in a weakened form, and has thereby given us the sense that we are doing work that meets its criteria of merit. Yet in providing us with that degree of legitimacy, the academy simultaneously defuses the political explosiveness of the positions we thought we were taking: it reinforces its definition of merit and gives us a stake in the maintenance of the system as it is. As discussions of the critique of rights have shown, these aspects of legitimacy have some benefits. The academy's standards of merit are not completely worthless, narrow though they may be, and being able to obtain a stake has often seemed to be necessary to sustain the effort to make even larger changes. But these benefits pose political problems for political movements, and it is as yet unclear that cls will be able to work its way around those problems.

For example, the rightward drift of United States politics will inhibit the recruitment of new adherents to cls. Those who enter law teaching will be drawn from a student body for whom the liberal legal reforms of the 1960's are at best old hat, and at worst examples of the overweening ambition of a "new class" of professionals grasping for power. The group may lean in the liberal direction, but the number of those considering themselves other than standard liberals is likely to be smaller than was the case when cls got started. ${ }^{97}$ The cultural-radical strand in cls draws on images of social connection often based upon recollections of the 1960's, which are unlikely to be available to new recruits at a high rate. ${ }^{98}$

95. Again, the point is suggested by the liberal academy's treatment of Brown v. Board of Education, 347 U.S. 483 (1954), and Goldberg v. Kelly, 397 U.S. 254 (1970), as paradigmatic cases of what courts actually do, rather than as cases to be considered in a course on legal history as representative of an era that, like the era of Lochner v. New York, 198 U.S. 45 (1905), has been over for a while. See Tushnet, Metaprocedure?, 63 S. CAL. L. REV. 161 (1989).

96. One indication of the mainstream academy's inability to settle on a way of doing policy science is the apotheosizing of the late Robert Cover, who taught at an institution that, as suggested by its hiring practices, appears to believe that one Cover is worth ten economists (which may actually have the multiplier right). The message may be, "Well, we may not have figured out what to do, but the fact that we revere Cover shows that we remain committed to the left of the political spectrum." I should also note my discomfort with the valuation of hierarchy that has attended Cover's entry into the pantheon, based on my belief that one reason Cover has entered the pantheon (while others equally admirable have not) is that he taught at Yale Law School.

97. As a result, it seems unlikely that the amoeba that is critical legal studies would move to occupy some territory, like that of law and literature or law and science, defined primarily with reference to intellectual approaches to the analysis of law. Adherents of those approaches would be available to cls only if they were predisposed to the political position occupied by cls and, I have argued, they are unlikely to be so predisposed.

98. Within cls, the cultural-radical strand causes a particular set of internal political difficulties. Much in that strand draws on what I call the fetishization of imagined connections, a romantic yearning that one's political location be a place of unalienated connectedness. See supra note 46 . The fetishization draws in part upon a reconstruction of the experience of the 1960's. Yet, as everyone who took part in the New Left knows, the politics of that movement was hardly the politics of a beloved community. People being who 
In addition, many cls adherents are likely to be underrecognized, a condition that potential recruits are likely to perceive. By "underrecognized," I mean that a substantial group of cls adherents, the white males, are likely to have positions at institutions lower in the status hierarchy of law schools than their merits entitle them to, as measured by the criteria of merit applied by most law professors and internalized to some degree by many adherents of cls. ${ }^{99}$ The reason is simple: recognition depends on perceptions and actions by widening circles of academics. Underrecognition occurs outside the circle of cls, as a result of hiring decisions by mainstream faculties. Men associated with cls and those who might support them for appointment are committed to increasing the numbers of minority and female scholars in the legal academy. Given a choice between a white male cls adherent and a minority or feminist scholar not associated with cls, their votes are likely to go differentially to the latter, wholly apart from whatever political misgivings people might have about cls. In contrast, people on the Right tend to be indifferent to considerations of diversity. At most they are willing to concede, grudgingly, that their traditional notions of merit ought to be changed somewhat, albeit for them, only in the cases of women and minorities. Their tolerance of deviance is likely to be exhausted when a woman or minority faculty member is hired. As the political dynamics in law school faculties play themselves out, the best result cls people can usually hope for is that the faculty will hire a woman or minority before it hires a less-qualified white male centrist or conservative; ${ }^{100}$ only in unusual circumstances will a white male adherent of cls displace the centrist or conservative in the hiring competition. ${ }^{101}$

On the whole, then, cls as such may not be a growth field. This analysis of the dynamics of underrecognition, however, brings us back to the more fundamental way of looking at cls: as a political location. That analysis indi-

they are, there were all sorts of personal tensions, competition for attention, and the like. When the reality of cls as a political location occupied by real live people comes up against the fetishization of imagined connections, serious tensions arise. (In my view, this describes the dynamics of every cls summer camp $I$ have attended, and many other cls events.)

99. The phenomenon would be unimportant if every potential adherent of cls were indifferent to considerations of hierarchy. Not all of us are. If it is necessary, I should add that I do not believe that $I$ am underrecognized.

100. The analysis in the text indicates that the following priorities will occur in hiring decisions: (1) mainstream white males; (2) "mainstream" women and minorities (the scare quotes indicating that women and minorities are necessarily out of the mainstream in some respects no matter what their scholarship or overt political affiliations); (3) women and minorities who identify with the Left, including those who present themselves as affiliated with cls; (4) white males who identify with the Left, including those who present themselves as affiliated with cls. (Because the criteria by which conservatives are evaluated differ from the ones discussed here, I cannot readily locate them on the scale just presented.) Thus, I do not suggest that of those associated with cls only white males are underrecognized, but only that structural reasons are likely to lead to a systematically greater amount of underrecognition of white males associated with cls.

101. I can imagine that a form of "product differentiation" might occur as some people unconsciously attempt to get around the problem of the "deviance quota" by presenting themselves as "not really cls but iomething else." It is a strategy well-known in legal education. When considering hiring someone "in" nternational law, for example, faculties are routinely urged to distinguish between public and private nternational law, and more recently between European and Pacific Rim international and comparative law. 
cates the importance of political alliances within the academy as part of the importance of cls.

The law and society influence on cls suggests that one set of allies might be found in the legal clinics at law schools. ${ }^{102}$ Live-client clinics almost universally represent the poor, and are therefore engaged in activity consistent with the political commitments of cls adherents. In addition, the clinics are places where students can observe the law-in-action, and learn how the concepts they see in appellate opinions translate into the actions of street-level bureaucrats, housing courts, and the like. Yet cls adherents and clinicians are likely to find themselves uneasy allies on particular issues, and at odds on others. The clinicians have been struggling to establish their legitimacy in the academy. Having gained a foothold but not much more, they reasonably might believe they have more to lose than to gain by linking up with a group itself not entirely welcome in the academy. Further, the focus in most cls work on the intricacies of mandarin legal thought, as expressed in appellate opinions and the writings of noted commentators, coupled with the cls use of out-of-theordinary work from other disciplines, does not fit easily with the daily work of clinicians. An alliance of these two out-groups might make sense, but the tensions in constructing such an alliance have so far been sufficient to limit severely the effectiveness of the cls-clinical connection. ${ }^{103}$

Other out-groups in the legal academy are minority and feminist scholars. They resemble cls in working out intellectual positions defined in substantial part by their opposition to mainstream legal thought, though of course the nature of the opposition is different. ${ }^{104}$ Many of these scholars, too, have assimilated more of the cls positions into their own work than have mainstream

102. I do not believe that the law and society movement, discussed in Friedman, The Law and Sociery Movement, 38 STAN. L. REV. 763 (1986), is likely to be a major source of new adherents of cIs. The law and society movement already includes a significant number of feminists and "political economists" who are associated with cls. Beyond those groups, the "pure" law and society people tend to be less interested in legal doctrine than most cls adherents are, and in any event they are quite marginal to the legal academy, which makes it unlikely that they will find it politically helpful to become associated with cls, On the other hand, the law and society movement, with its origins in efforts to promote progressive legal reform, has been unable to gain more than a toehold in the legal academy. (For example, the editors of the The Yale Law Journal did not think it important to invite a contribution to this issue from someone prominently associated with the law and society movement.) This may induce its members to associate themselves with one group of progressive lawyers already part of the pluralistic universe of the legal academy, that is, with critical legal studies.

103. Identifying critical legal studies as a political project associated with the legal academy explains why it has been difficult to attract significant numbers of practicing lawyers into long-term relations with cls. The amoeba that is cls might extend to include significant numbers of practicing lawyers, but the dynamics of recruitment and retention, which seem to me heavily focused on the legal academy, make that unlikely.

104. My formulation should make it clear that I do not regard all feminist and minority scholars as already adherents of, or even as potential adherents of, critical legal studies. I do regard such scholars as necessarily oppositional within the legal academy, though in complex ways. But if, as I have argued, cls is a political location, there is no particular reason to believe that it must necessarily fully occupy the terrain of oppositional politics within the legal academy. 
academics. ${ }^{105}$ These groups are likely to mix outrage at and acceptance of the status quo in proportions closer to cls than to the legal mainstream. Of course, the overall agendas of these several groups differ, as is true in any political alliance, and the present balance of power in the legal academy is such that the feminist and minority scholars are likely to capture more of the benefits of the association than are white male cls adherents. Even so, the prospect of sustained political connections among these groups seems reasonably good.

Finally, there is the liberal mainstream. For good reason, many liberal academics do not find cls adherents easy to live with. At the same time, they understand that public policy in the United States has moved more substantially to the right than they find really comfortable. They sense, even if they cannot bring themselves to face up to the implications of the fact, that the Warren Court era is now roughly like the Lochner era in being an interesting but closed period in the history of the Supreme Court. And they know that they, like their liberal colleagues in other disciplines, have not come up with credible intellectual/policy-science defenses of the social welfare policies to which they are committed. In these circumstances, cls people are, faute de mieux, natural political allies for the liberal mainstream.

Taking the intellectual circumstances of cls together with its political environment, then, we may understand why cls is likely to remain one element in the pluralistic universe of the legal academy, but not much more. In one sense, of course, this demonstrates the success of the project of developing a political location to support the Left in the legal academy. One indication of this is the prevalence of statements dismissing cls as "merely legal realism with an unnecessary radical politics, and pointless anyway since 'we are all legal realists now." "The first point may perhaps be accurate, but the second seems to me not to be. What was taught at Yale Law School in the 1970's and what its faculty writes today may be legitimate successors to legal realism, but critical legal studies managed to revive a view of the law associated with legal realism that had been lost for a generation.

It is not beyond the bounds of possibility, of course, that the opponents of critical legal studies may overplay their hands and drive centrist liberals toward the left. As a story in The New York Times revealingly put it:

One wonders if [Harvard Law School] Dean [Robert] Clark's reaction-his corporate boosterism, his emphasis on ivory-tower excellence, his less than impassioned commitment to the public interest, broadly defined - may not create divisions within the law school that are deeper than the Critical Legal Studies rift. The danger [sic] is that the fault line at Harvard Law School, by shifting rightward, will isolate its adminis-

105. Compare, e.g., West, Jurisprudence and Gender, 55 U. CHI. L. REv. 1 (1988) and West, Feminism, Critical Social Theory and Law, 1989 U. CHI. LEGAL FORUM 59 (both sympathetically critical of cls positions) with Fiss, The Death of the Law?, 72 CORNELL L. REV. 1 (1986) (critical but not so sympathetic). 
tration and leave those professors in the middle on the same side of the chasm as the Crits. ${ }^{106}$

I suspect that, on the whole, administrators of law schools who have a less exalted sense of the importance of their activities are likely to respond more sensibly to the threat they feel from critical legal studies, ${ }^{107}$ and will allow critical legal studies to remain part of the pluralistic universe. Who could reasonably have asked for the academy to welcome this disruptive political presence with open arms?

106. Emerson, When Legal Titans Clash, N.Y. Times, Apr. 22, 1990, $\S 6$ (Magazine), at 69. Again I should note that I am reluctant to attribute apocalyptic effects even to a complete cls success at Harvard Law School, even given the importance of Harvard Law School in the status hierarchy of legal education. 107. Given the venue of this Article, I think it important to note at least once that the reception of cls at Yaie Law School rather strongly suggests that it is not among the law schools responding sensibly to the threat they perceive from critical legal studies. 